\title{
Water Erosion Mapping by RUSLE: A Geomatic Approach by GIS and Remote Sensing in the Oued Isser Watershed, Tlemcen, Algeria
}

\begin{abstract}
Prolonged water erosion leads to severe soil degradation, with highly visible scars. Consequently, the quantitative and descriptive estimation by mapping of the phenomenon has become the main objective of a great deal of research. It is this perspective that this study takes, based on the Revised Universal Soil Losses Equation (RUSLE) for a relatively accurate estimate, by integrating ArcGIS tools and remote sensing using high spatial resolution $(10 \mathrm{~m})$ image from the Sentinel-2A satellite. The model uses data on precipitation, soil, topography and vegetation cover management. The methodological approach taken implements this model in order to optimize its use by the various potential users in their planning and decision-making studies. An application was carried out in the Oued Isser watershed (Tlemcen, Algeria). Soil loss maps were produced and the results indicate a high variation in soil losses in the study area and show that the highest values are concentrated on steep slopes, hence the great influence of the topographic parameter relative to other factors in the model.
\end{abstract}

Keywords: water erosion, RUSLE, ArcGIS, remote sensing, the Oued Isser watershed

Received: 29 November 2020; accepted: 4 January 2021

(C) 2021 Authors. This is an open access publication, which can be used, distributed and reproduced in any medium according to the Creative Commons CC-BY 4.0 License.

1 University of Saïda - Dr. Moulay Tahar, Water Resources and Environment Laboratory, Saida, Algeria, email: talbio@yahoo.fr, ORCID ID: https://orcid.org/0000-0002-0294-5070

2 University of Saïda - Dr. Moulay Tahar, Modelling and Calculation Methods Laboratory, Saida, Algeria, email: belaidfatmi1@gmail.com, ORCID ID: https://orcid.org/0000-0002-4647-6544

3 Algerian Space Agency, Centre of Spatial Techniques, Earth Observation Department, Oran, Algeria, email: khatir@dr.com, ORCID ID: https://orcid.org/0000-0003-4419-2668

4 University of Saïda - Dr. Moulay Tahar, Water Resources and Environment Laboratory, Saida, Algeria, email: tal_djdz@yahoo.fr, ORCID ID: https://orcid.org/0000-0002-7849-6996 


\section{Introduction}

The harmful consequences of water erosion, on soil loss and degradation, on agricultural production, on water quality and quantity, on hydrological systems and the environment, have been recognized for a long time as serious problems for sustainable development. As a result, the descriptive and especially quantified evaluation of water erosion has become urgent [1]. Estimation of water erosion and soil losses is often difficult due to the complex interaction of its many factors:

- climate,

- soil,

- vegetation cover,

- topography,

- human activities.

Research has been devoted to the phenomenon in question for a long time. Thus, many empirical models, of soil losses estimation due to water erosion, have been developed [2, 3]. The Universal Soil Loss Equation (USLE) and later the Revised USLE (RUSLE) were the most used models for predicting water erosion soil losses [4-15].

Initially, the USLE model was developed to estimate soil erosion of cultivated land on a soft sloping topography [2]. This model has undergone numerous revisions and modifications to become RUSLE; its application was then expanded to different scales and situations, including forests and rangelands. The input parameters of the model were generally estimated or calculated using field measurements at a parcel scale. Soil loss quantification methods based on the erosion plots have many limitations, in particular the representativeness and reliability of the obtained results. This is why mapping soil erosion at large scales over large areas is often more difficult using these standard methods. Thus, a geomatics approach using spatial tools such as geographic information systems (GIS) and remote sensing makes the quantification and spatial distribution mapping of soil loss easier, with better accuracy and rational costs, particularly when applied over large areas [16]. This approach provides the opportunity to estimate the potential and actual loss of soils due to water erosion at the cell (or pixel) scale. In geomatic terms, GIS offers tremendous potential for managing geographic information; while remote sensing constitutes an inexhaustible source of information, as well as a frequently updated database.

In this study, high spatial resolution $(10 \mathrm{~m})$ remote sensing image from the Sentinel-2A satellite was used to highlight and map land use activities and vegetation cover in the study area. The ArcGIS tool was used to capture, manage, calculate, analyse and output all model data and parameters in the form of maps or attribute tables.

This article aims to supplement the field of water erosion with new advances in the management of geographical information. In this case, the RUSLE model implementation and its application at the level of the watershed of the Oued Isser area in western Algeria. 


\section{Materials and Methods}

\subsection{Study Area}

The study area (Fig. 1) concerns the Oued Isser watershed in the sector of Ain Nehala, about $40 \mathrm{~km}$ from the city of Tlemcen in North-West Algeria with a total area of around 2300 ha. The choice of the area mentioned was dictated by the erosive nature of this region and the availability of input data from the RUSLE model, in particular its soil and land use data.
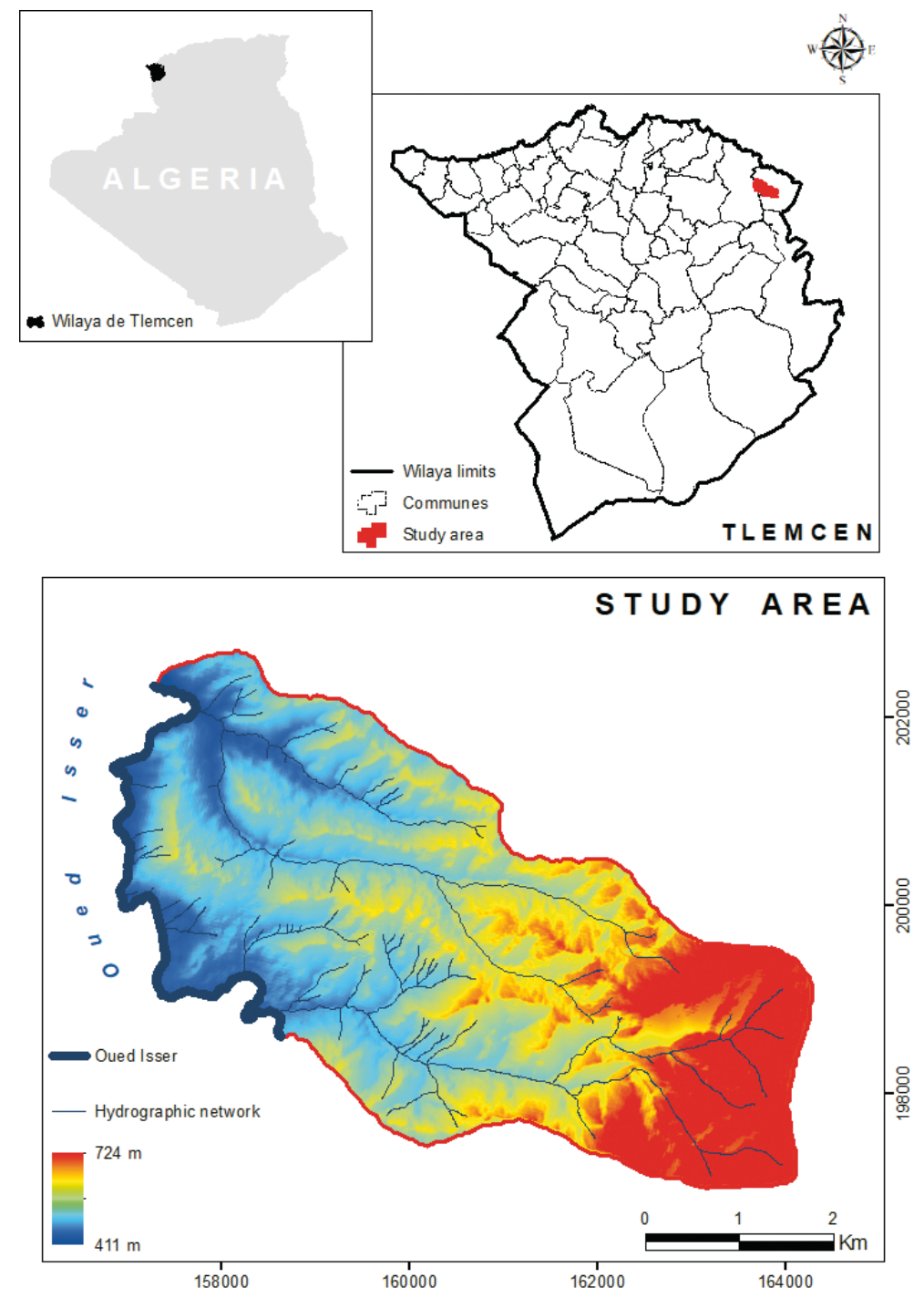

Fig. 1. The study area 
The region's climate is of the Mediterranean type, dominated by extended summer droughts and often accompanied by high daytime temperatures. These temperatures play an important role in the humectation and desiccation cycle of soil aggregates. The region is characterized by an average annual temperature of $18.7^{\circ} \mathrm{C}$. The wet period is marked by violent and stormy showers during the summer and autumn seasons. In spring and winter, rainfall is infrequent but of long duration, which causes considerable damage. Note that the prolonged, low-intensity rains that fall in winter on saturated soils over large areas with little cover cause the highest peak flows in gullies and wadis [17]. The average annual rainfall in the basin recorded during the last 25 years (1994-2019) is around $445 \mathrm{~mm} /$ year. The altimetry of the area varies between 411 and $724 \mathrm{~m}$ above sea level and the mean elevation around $550 \mathrm{~m}$.

\subsection{Description of the Model Used}

The RUSLE model given by Formula (1) represents how climate, soil, topography and land use affect water erosion, which is initially caused by the impact of raindrops (splash effect) and then by surface runoff [3]. Currently, the RUSLE model is the subject of a large amount of research, the main objective being the estimation of soil losses and soil water erosion risk [5-7, 12, 14]. The potential user will be assisted in the establishment and development of conservation plans for controlling the phenomenon. The RUSLE model is formulated as follows:

$$
A=R \cdot K \cdot L S \cdot C \cdot P
$$

where: $A$ is the average annual soil losses [t/(ha·year)], $R$ is the rainfall-runoff erosivity factor $[\mathrm{MJ} \cdot \mathrm{mm} /($ ha $\cdot$ year.h)], $K$ is the soil erodibility factor $[\mathrm{t} \cdot \mathrm{h} /(\mathrm{MJ} \cdot \mathrm{mm})], L S$ is the topographic factor, $C$ is the land cover and management factor and $P$ is the cultural and anti-erosion practices factor.

\subsection{Exogenous Data}

The application of the model expressed by the Formula (1) requires the combination of multiple parameters. Thus, several data sets were collected and organized as input data for the model in order to produce the required geographical information layers.

To determine the rainfall and runoff erosivity index $(R)$, precipitation data from six meteorological stations recorded over a 25-year period (1994-2019) were integrated. The soil erodibility factor $(K)$ was generated from the soil map of the study area and the different soil unit analyses [18]. Water erosion also depends on the morphometric parameter (LS), the calculation of which requires the use of a digital elevation model (DEM), available in raster format with an initial spatial resolution of $10 \mathrm{~m}$ (Fig. 1). Land use and vegetation cover factor $(C)$ maps were obtained from the processing and analysis of a high spatial resolution image $(10 \mathrm{~m})$ from the European Sentinel-2A satellite acquired on 7 July 2019. 


\section{Methodology}

\section{1. $R$ Factor}

Erosivity reflects the potential of rainfall to cause the water erosion of soils. To estimate this index, the model (2) of Rango and Arnoldus [12] was applied, using data from six meteorological stations covering the study area. The rainfall data collected correspond to a period of 25 years (1994-2019):

$$
\log R=1.74 \cdot \log \Sigma\left(P_{i}^{2} / P\right)+1.29
$$

where $P_{i}$ is the monthly rainfall and $P$ is the annual rainfall [mm].

The erosivity factor $R$ for each weather station was calculated by kriging interpolation using the ArcGIS software to derive the following map (Fig. 2).

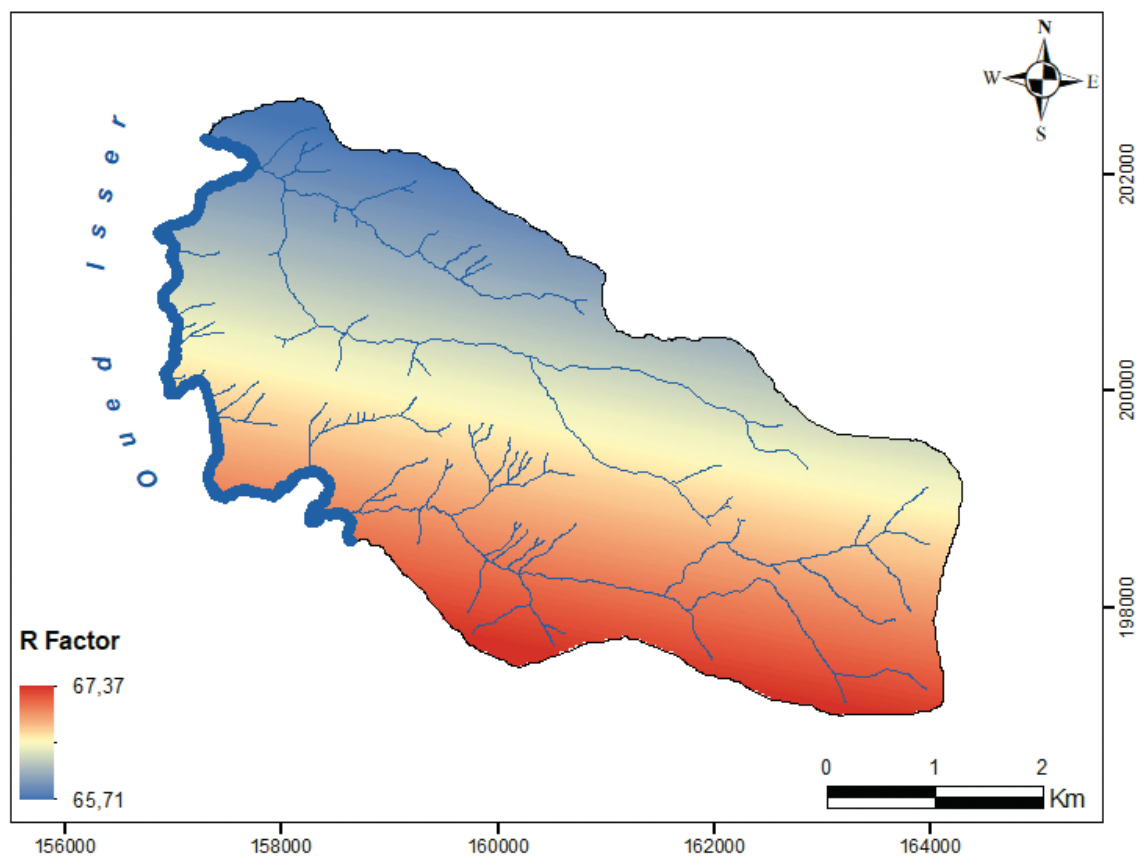

Fig. 2. The $R$ factor map

\section{2. $K$ Factor}

Some soils erode more easily than others, although all other "external" factors are the same. This difference is due to the properties of the soil itself, recognised as its erodibility $K$. It is the relative aptitude or resistance of soils to water erosion processes. 
Soil surveys carried out in the study area [18] showed the presence of ten soil units (Tab. 1), regrouped into three main categories: calcimagnesic, isohumic and poorly developed soils (Fig. 3). All of these soil units have a slow to average permeability at the surface, which decreases with depth.

Table 1. The different soil units of the study area

\begin{tabular}{|c|l||}
\hline Unit & Description (according to U.S. Department of Agriculture) \\
\hline \hline 1 & Lithic xerochrept thermic fine silt \\
\hline 2 & Typic calcixerolic xerochrept thermic clayey \\
\hline 3 & Vertic calcixerolic xerochrept thermic clayey \\
\hline 4 & Typic xerochent thermic clayey \\
\hline 5 & Calcixerolic xerochrept thermic fine loamy \\
\hline 6 & Vertic xerochrept thermic clayey \\
\hline 7 & Typic calcixerolic xerochrept thermic fine silty \\
\hline 8 & Vertic xerochrept thermic clayey \\
\hline 9 & Ultic xerochrept thermic clayey \\
\hline 10 & Regosol \\
\hline
\end{tabular}

Source: [18]

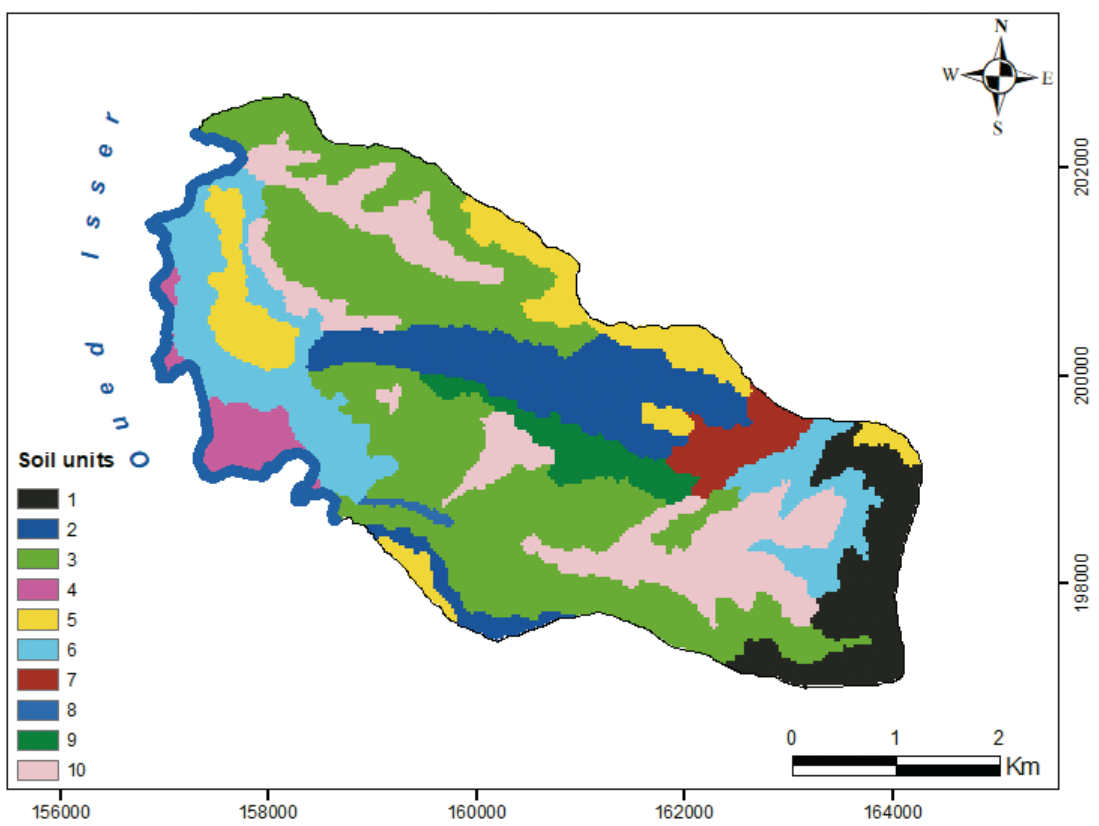

Fig. 3. The soil units of the study area

Source: [18] 
The K-index was calculated for each soil unit using Formula (3). It is a mathematical model based on the Wischmeier empirical nomograph [2] and requires data on granulometry, organic matter content, structure and permeability of the different soil types:

$$
K=1 / 100 \cdot\left[2.1 \cdot M^{1.14} \cdot 10^{-4} \cdot(12-M O)+3.25 \cdot(P-2)+2.5 \cdot(S-3)\right]
$$

where: $M=(\%$ fine sand $+\%$ silt $) \cdot(100-\%$ clay $), O M$ is organic matter percentage, $P$ - soil permeability code and $S$ - soil structure code.

The result (Fig. 4) shows the variability of the erodibility coefficient $(K)$, which ranges from 0.20 for soils with high structural stability to 0.55 for soils that are relatively rich in fine elements and therefore easily erodible.

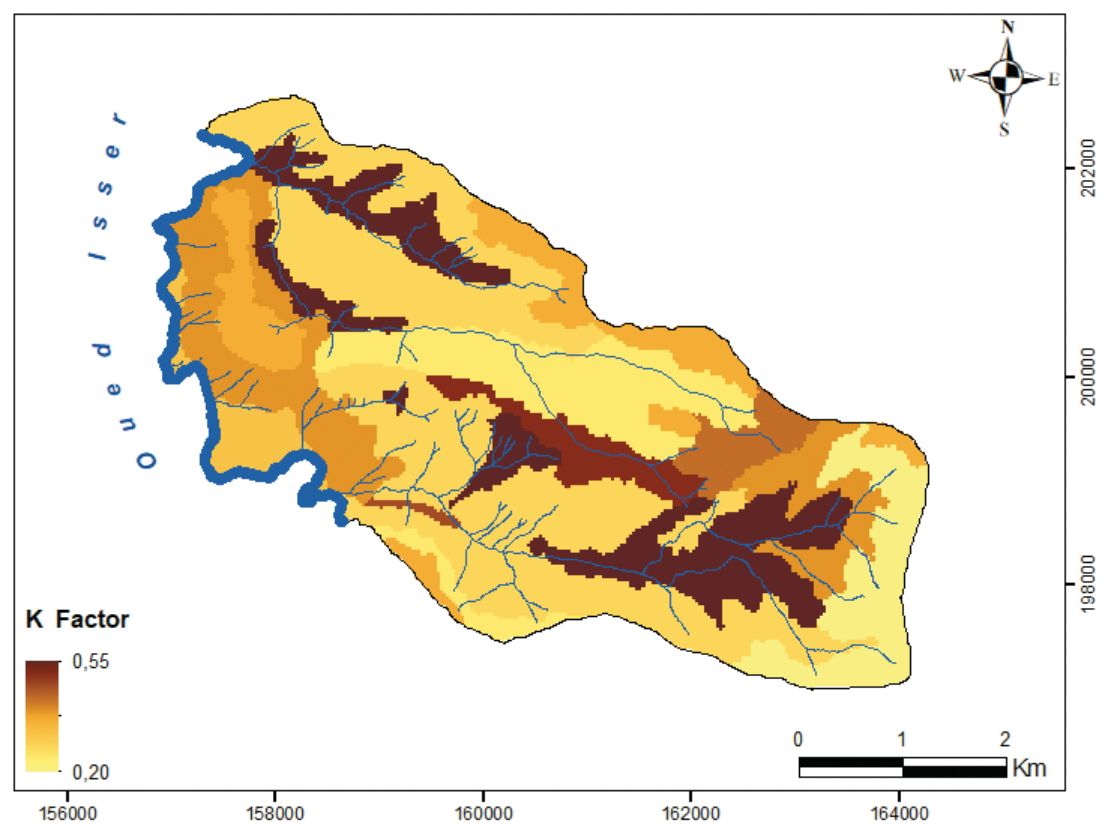

Fig. 4. The $K$ factor map

\subsection{LS Factor}

This parameter highlights the topomorphology of the study area, by combining the effect of the slope degree and its length by Equation (4):

$$
L S=(L / 22.15)^{m} \cdot\left(65.41 \cdot \sin S^{2}+4.56 \cdot \sin S+0.065\right)
$$

where: $L$ is the slope length, $S$ is the slope expressed in degrees and $m$ is the slope length exponent variating according to slope $S ; m=0.5$ if the slope $\geq 5 \%, m=0.4$ for slope between 3.5 and $5 \%, m=0.3$ for slope between 1 and $3.5 \%$ and $m=0.2$ if the slope $<1 \%$. 
The extraction of the top morphological parameters required the use of a DEM in the form of a raster image (Fig. 1). The DEM used was georeferenced and pre-processed using ArcGIS modules in order to correct any imperfections such as altimetric discontinuities.

The GIS permitted the calculation of the slope $(S)$ and its length $(L)$, based on determining the flow direction of each cell (pixel), then measuring the longest climb distance along the flow path from each cell to the water split line. By introducing the necessary input data for estimating the dimensionless $L S$ factor, Formula (4) was applied to establish the topomorphological effect map (Fig. 5).

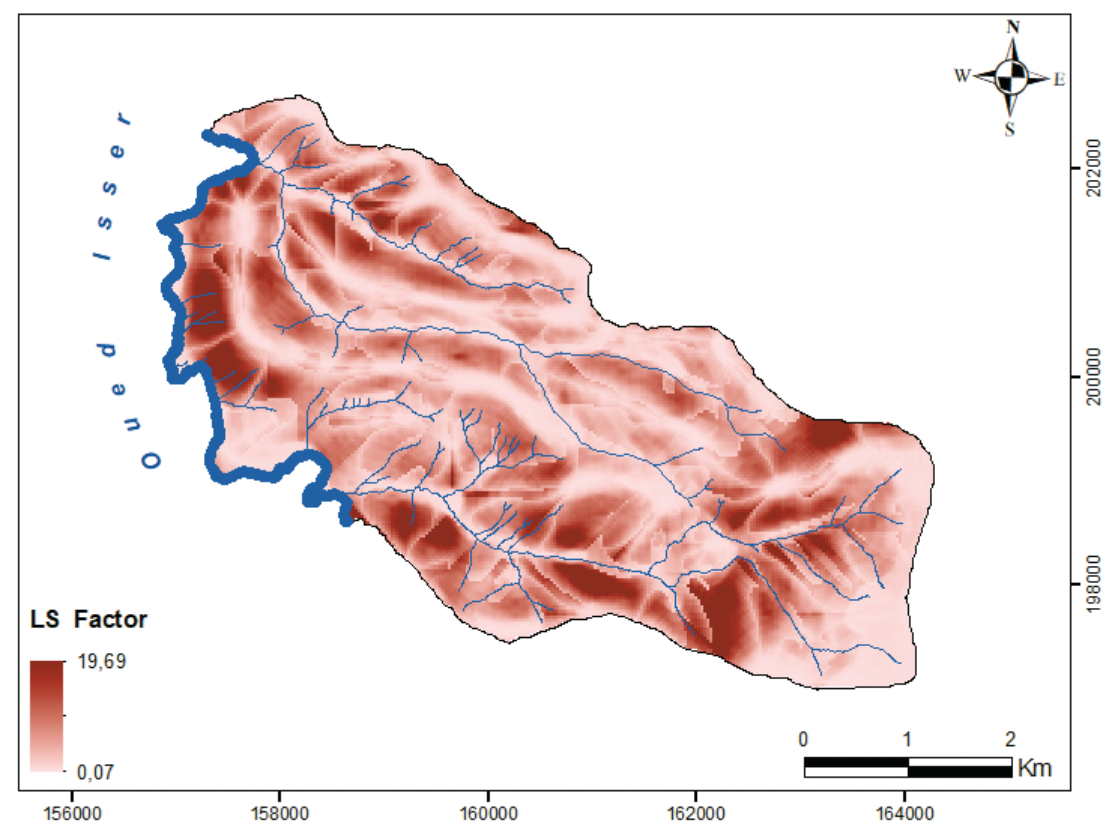

Fig. 5. The $L S$ factor map

The results obtained show that the values of this parameter are coherent with the field reality. It has been observed that the greater values are concentrated at the level of the most accentuated slopes; while the lowest values are located at the ridge lines and streams.

\subsection{Factor}

The vegetation cover designated by parameter $C$ is an important factor in soil protection from water erosion. It should be noted that where the vegetation cover is denser, the less the soil is exposed to this phenomenon. This is a determining parameter for the Wischmeier erosion model because it is more dynamic. 
This parameter is decisive in the protection and sustainable development of the environment against the water erosion, knowing that biological protection methods of soil remain the most effective and economical solution for the medium and long terms periods. Therefore, the precise determination and updating of this parameter is necessary to ensure the proper monitoring of the water erosion process.

The study area is an agricultural region characterized principally by seasonal agricultural practices. This type of land use is often threatened by water erosion. For this purpose, the availability of land cover map constitutes a key element to get the idea about the type of land-use in the study area. Land cover mapping was performed using the Sentinel-2A image data. This image was processed through a supervised classification method using field representative samples. This operation permitted the identification of the different land use classes in the study area (Fig. 6).

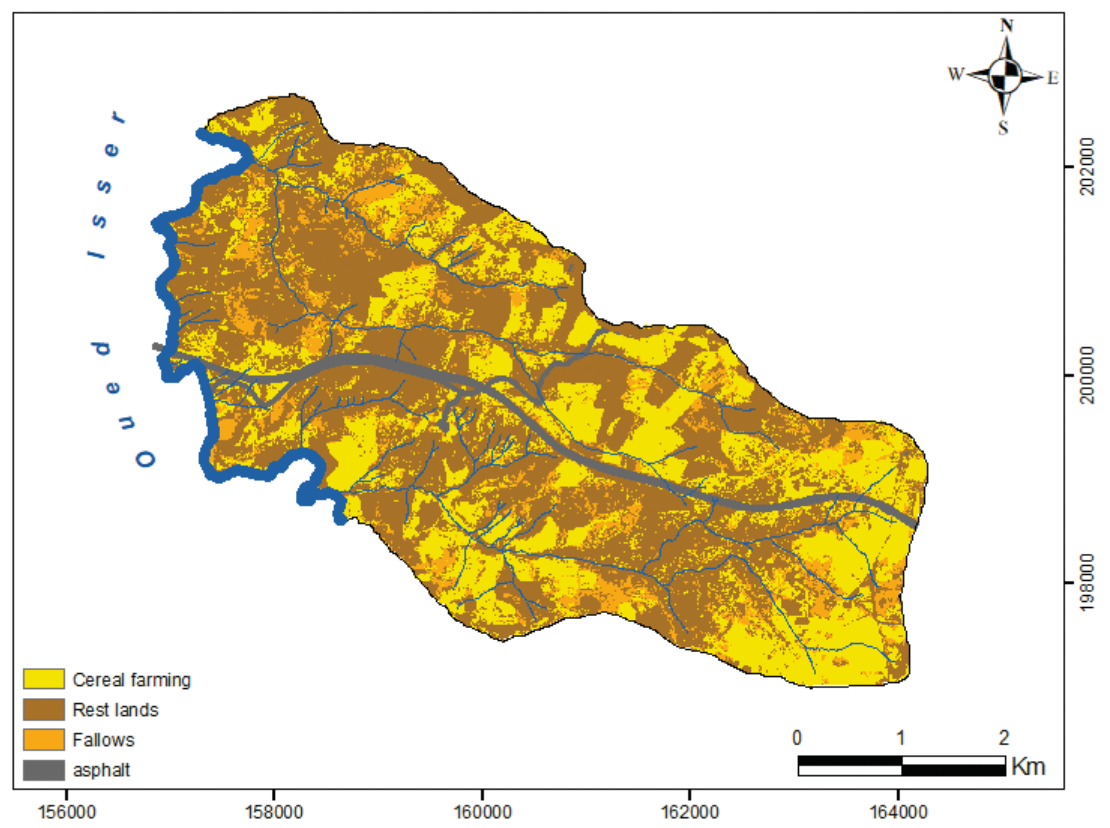

Fig. 6. The land use map

The map produced shows three major classes including cereal growing areas (cereal farming), areas placed in rest to be cultivated next season (rest lands) and finally unproductive and abandoned lands (fallows). Another non-significant class of the road network is present on the map, since the study area is traversed from east to west by the A1 motorway.

Statistics show that cereal farming and rest lands occupy around $90 \%$ of the total area. The remaining 10\% represents unproductive and rugged land. This means 
that the investigated area is of an agricultural character, hence water erosion (splash and run-off) causes soil loss problems during the autumn and summer rainfalls.

Usually, the $C$ factor is derived from empirical work based on the monitoring of a multitude of variables related to vegetation cover and collected on sample plots. The values of factor $C$ at the unsampled locations are estimated using spatial interpolation techniques. This classical approach is time intensive and requires a lot of data which are often unavailable [14].

Many mathematical models have been developed [12, 19, 20], which all have in common the ability to express the correlation that exist between the NDVI (Normalized Difference Vegetation Index) and the vegetation cover (factor $C$ ). In this work, we opted for the model given by Equation (5) [19] where the relationship between the NDVI index and $C$ factor is written as follows:

$$
C=\exp [-2 \cdot \mathrm{NDVI} /(1-\mathrm{NDVI})]
$$

with NDVI $=(\mathrm{PIR}-R) /(\mathrm{PIR}+R)$, where PIR and $R$ are respectively the near infra-red and red channels.

The ratio between the red and infrared bands of the pre-processed Sentinel-2A image produced the vegetation index map using ArcGIS tool. This map highlights the chlorophyll activity of the vegetation cover in the study area (Fig. 7).

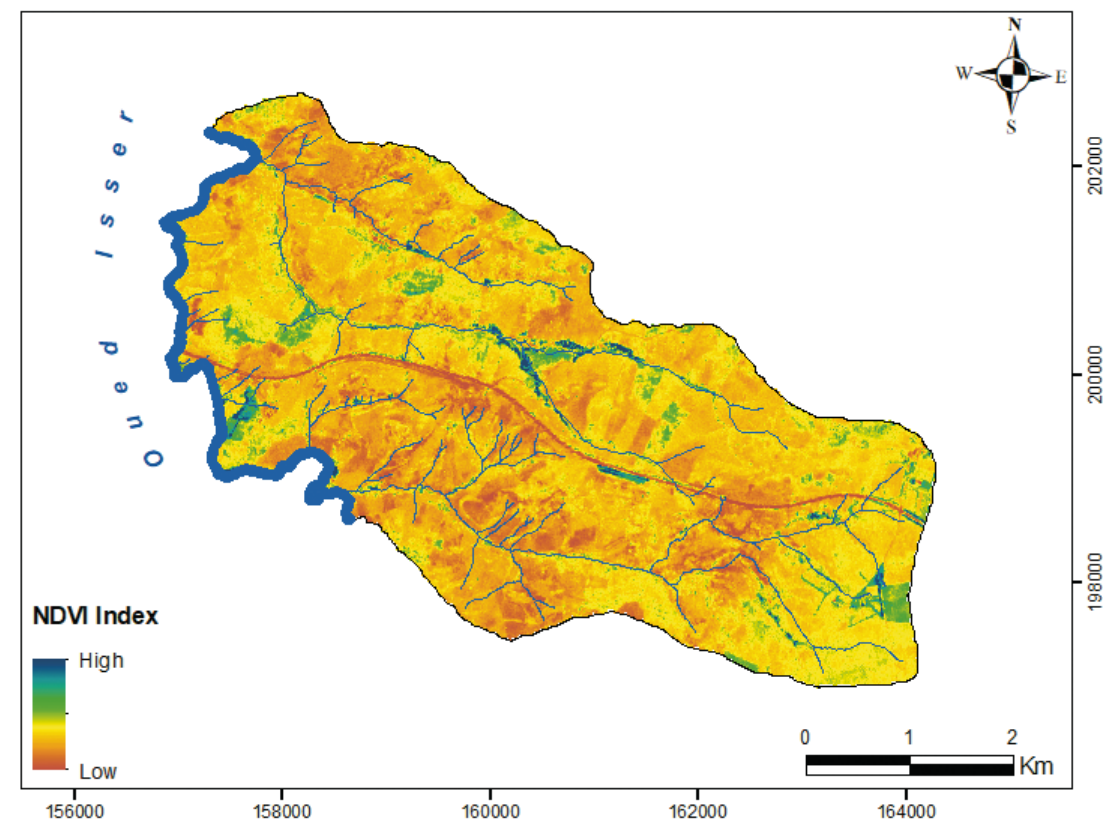

Fig. 7. The NDVI index map 
The low values displayed in a brown to yellow colour reveal poor or no vegetation activities, i.e., soils are vegetation clear or completely bare soil. However, the green values reflect the existence of vegetation cover such as orchards, scrublands and small forest reforestations. The resulting NDVI map shows the presence of weak vegetation cover in most of the study area at this period of the year. This suggests the high vulnerability of soils to water erosion in this region.

The estimation of the parameter $C$ related to the vegetation cover expressed by Equation (5) was performed using ArcGIS, giving values ranging from a minimum of 0.16 to a maximum of 1 (Fig. 8). The high values represent non-vegetated soils (resting, bare soils), while the low values indicate the presence of vegetation. The highest values, close to 1, correspond to the "asphalt" class of the motorway A1 crossing the area. This proves a certain coherence to the reality on the ground surface and therefore the effectiveness of the model adopted. The $C$ index statistics give a mean of 0.83 and a standard deviation of 0.06 . Thus, most of the measured values of this parameter are concentrated around the given mean, i.e. close to 1 , which proves the vulnerability of the area studied to water erosion in summer, when most soils are almost devoid of vegetation.

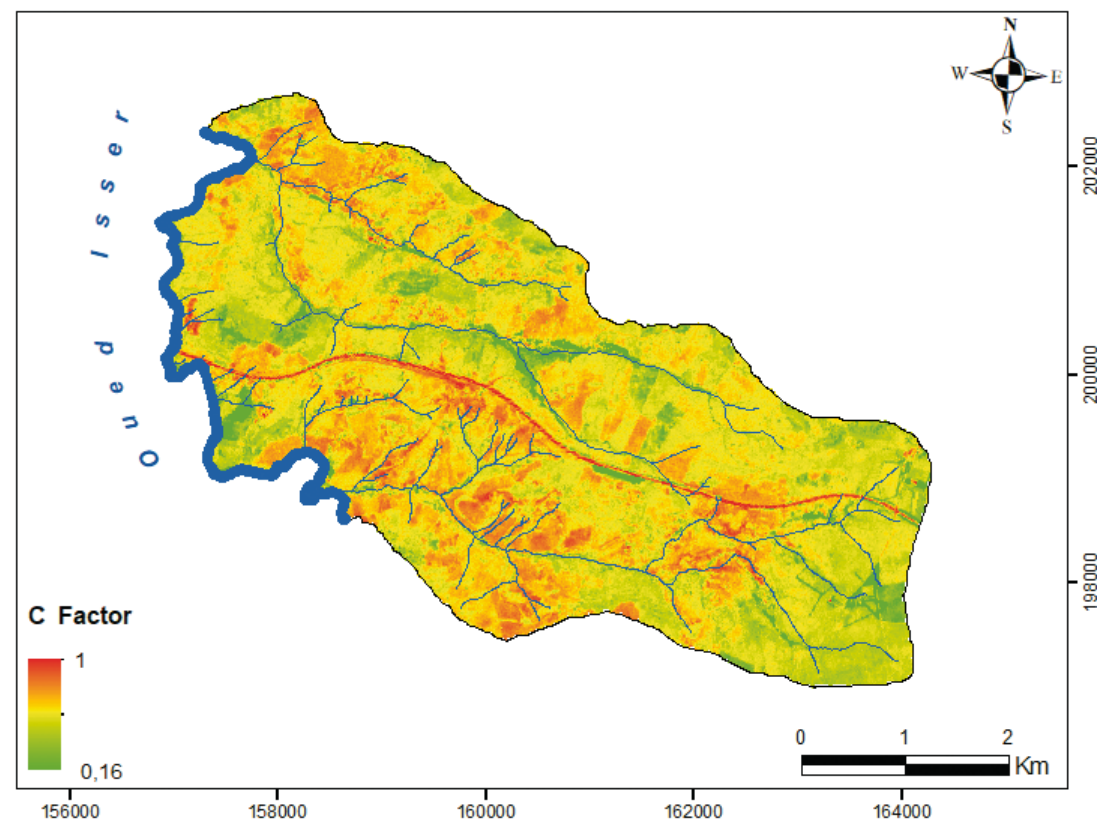

Fig. 8. The $C$ factor map

The $C$ index statistics give a mean of 0.83 and a standard deviation of 0.06 . Thus, most of the measured values of this parameter are concentrated around the given mean, i.e. close to 1 , which proves the vulnerability of the area studied to water erosion in summer, when most soils are almost devoid of vegetation. 


\section{5. $P$ Factor}

The $P$ factor characterizes the effect of anti-erosion cultural practices. These protection methods are absent across the study area. Consequently, $P$ is considered to be constant $(P=1)[9,11,14]$.

\section{Results and Discussions}

By determining the input parameters of the model (1) in the form of geographical information layers, their overlay using the ArcGIS tool enabled the application of the RUSLE model and the production of a set of synthetical maps corresponding to the erosive potential and soil losses.

\subsection{Erosive Potential Map}

The erosive potential map (Fig. 9) was produced by combining the static physical parameters of the model used, i.e. $R, K$ and $L S$.

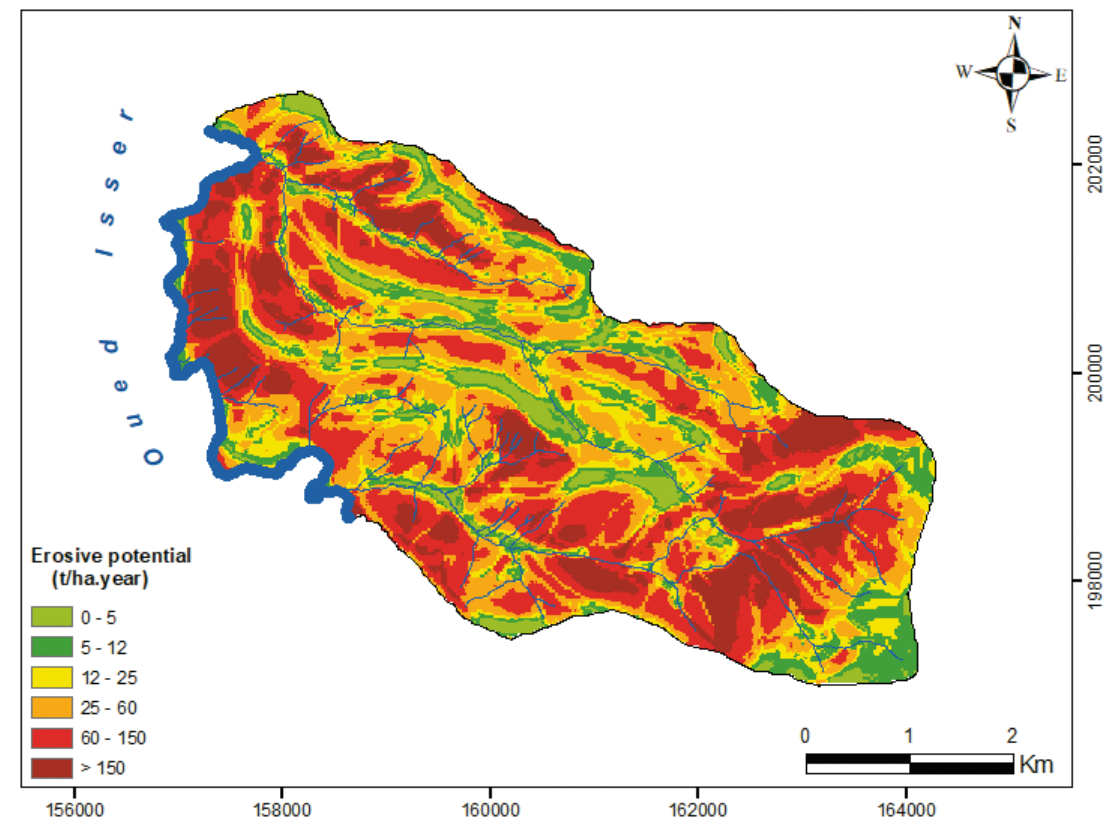

Fig. 9. The erosive potential map

Indeed, the soil is therefore assumed to be bare, with no vegetation $(C=1)$. The map of erosive potential characterizes the real risk to which the soil is exposed independent of vegetation cover, and the cultural and anti-erosion practices that are assumed to be "dynamical". In this case, the given statistics provide a potential annual 
average nearly $75 \mathrm{t} /$ (ha·year). Such a map can be useful for field experts and/or planners in carrying out vulnerability analyses of the study area and in their decision-making studies.

\subsection{Soil Loss Map}

The result below (Fig. 10) represents the soil loss map of the study area obtained by combining all of the geographical information layers related to the erosive factors listed in this research.

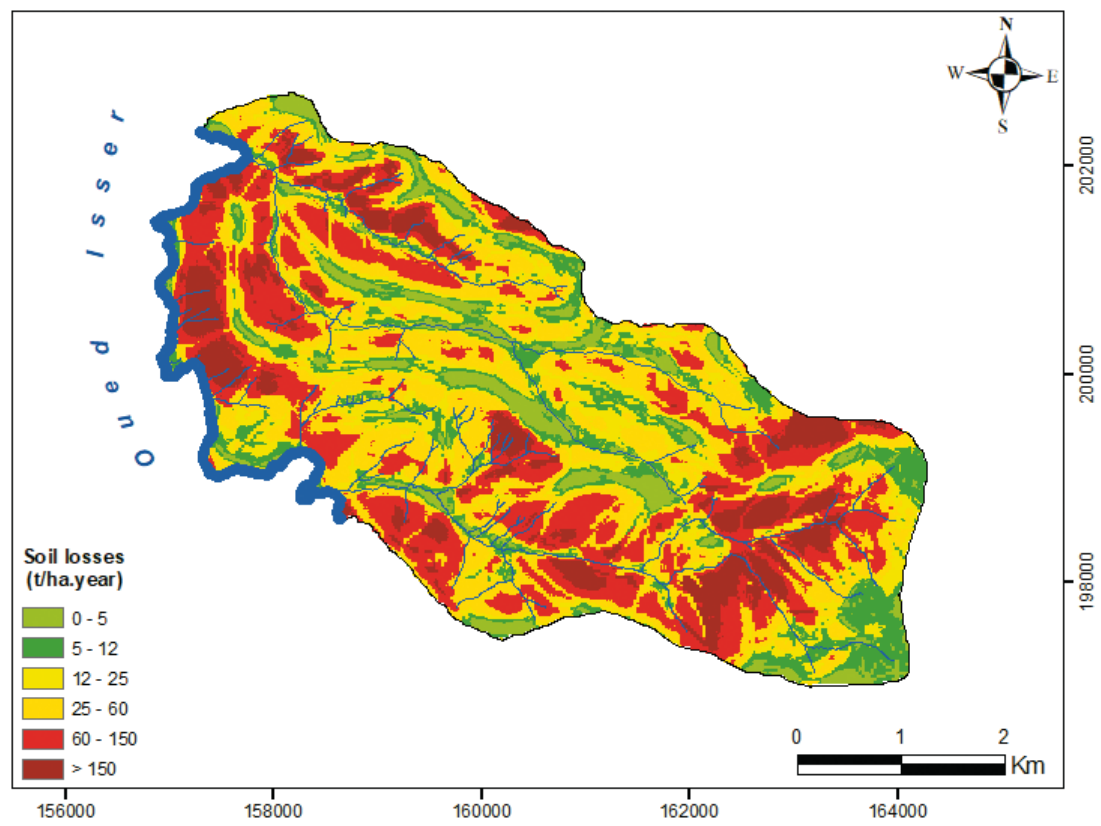

Fig. 10. The soil loss map

According to this map, the average annual soil loss is about $62 \mathrm{t} /$ (ha.year). This is more than $17 \%$ less than the average erosive potential, which reflects the importance of vegetation cover in protecting soils against water erosion. Soil losses in the study area vary between 0 and $570 \mathrm{t}$ /(ha.year) and their spatial distribution is much more influenced by the topomorphological parameter. Thus, the greatest soil losses are located in rugged areas with steep slopes.

\section{Conclusion}

In general, RUSLE is used to estimate average annual land losses. The use of GIS and remote sensing has allowed the spatial distribution of quantities to be 
mapped, along with the water erosion risk. Four parameters derived from different data sources, with different spatial formats, projections, quality and resolution, such as climate, soil, DEM and remote sensing data, were used in the application of the erosion model. Consequently, the use of GIS has facilitated the input, management, processing, and analysis of the different data and results. More attention must be accorded to the assessment and pre-processing of the data prior to their use in order to avoid possible errors in the estimation of soil losses.

Mapping soil erosion over a large area is difficult and above all the validation of the results that is not always easy. This article focuses on the geomatic aspect for estimating soil erosion at the level of the Oued Isser watershed. It is recommended to compare this with similar studies that use different methodological approaches.

The study is based on the combination of the RUSLE model, GIS, and remote sensing tools. All three tools together provide an efficient system for mapping the spatial distribution of soil erosion risks over a large area. This work can be a useful tool for the potential users, enabling them to properly manage and plan land use activities. In particular, the establishment of a reliable and updated diagnosis of water erosion remains a key element for the development of studies and decision-making.

The results of the study indicate a high variation in soil losses in the study area. Their quantity and spatial distribution are influenced more by the topographic parameter than the other factors of the model.

The model using RUSLE has its limitations. indeed, it can only be applied to average values over 20 years, nor does it apply to rainfall scale. It is therefore necessary to have data over a long period of time, which is not always possible. In the case of this study, rainfall data over 25 years were used. Initially, the data used to establish that this model concerned small plots $\left(100 \mathrm{~m}^{2}\right)$ or small watersheds (a few hectares). Attention must therefore be given to the problems of scale if larger areas are considered. The interactions between the different parameters are not taken into account, although many studies have shown that these interactions certainly exist. Despite all these limitations, it must be recognised that this model reveals its practical usefulness in the field.

In the future, national and international collaboration is planned in order to generalize and validate the application of this model, especially with regard to the determination of its different parameters which must be refined for more accurate results.

\section{References}

[1] Boughalem M., Ienciu A.A., Toure A.O., Meghraoui M., Regagba M., Souidi Z., Hamimed A.: Study of water erosion risk in the region of Tlemcen, Algeria. Geo-Eco-Trop, no. 44, t. 4, 2020, pp. 595-607. 
[2] Wischmeier W.H., Smith D.D.: Predicting Rainfall Erosion Losses: A Guide to Conservation Planning. Agriculture Handbook, no. 537, U.S. Department of Agriculture, Washington 1978.

[3] Renard K.G., Foster G.R., Weesies G.A., McCool D.K., Yoder D.C.: Predicting Soil Erosion by Water: A Guide to Conservation Planning with the Revised Universal Soil Loss Equation (RUSLE). Agriculture Handbook, no. 703, United States Department of Agriculture, Agricultural-Research Service, 1997.

[4] Ezzaouini M.A., Mahé G., Kacimi I., Zerouali A.: Comparison of the MUSLE Model and Two Years of Solid Transport Measurement, in the Bouregreg Basin, and Impact on the Sedimentation in the Sidi Mohamed Ben Abdellah Reservoir, Morocco. MDPI. Water, vol. 12, no. 7, 1882, 2020. https://doi.org/10.3390/w12071882.

[5] Mihi A., Benarfa N., Arar A.: Assessing and mapping water erosion-prone areas in northeastern Algeria using analytic hierarchy process, USLE/RUSLE equation, GIS, and remote sensing. Applied Geomatics, vol. 12, no. 2, 2020, pp. 179-191. https://doi.org/10.1007/s12518-019-00289-0.

[6] Sahli Y., Mokhtari E., Merzouk B., Laignel B., Vial C., Madani K.: Mapping surface water erosion potential in the Soummam watershed in Northeast Algeria with RUSLE model. Journal of Mountain Science, vol. 16, no. 7, 2019, pp. 1606-1615. https://doi.org/10.1007/s11629-018-5325-3.

[7] El Hafid D., Akdim B.: Quantification de l'érosion hydrique en utilisant le modèle RUSLE et déposition intégrée dans un SIG - Cas du bassin versant de l'oued Isly (Maroc Oriental). European Scientific Journal, vol. 14, no. 5, 2018, pp. 1857-7881. https://doi.org/10.19044/esj.2018.v14n5p373.

[8] Koussa M., Bouziane M.-T.: Contribution of GIS to the mapping of water-erosion risk areas in the Beni Haroun watershed, Mila, Algeria. Geo-Eco-Trop, no. 42, t. 1, 2018, pp. 43-56.

[9] Kaci M., Habi M., Morsli B.: Application of universal soil loss equation (USLE) model to estimate water erosion by GIS system and remote sensing: Case of catchment area of Oued Rhiou (Watershed of Cheliff), Algeria. Geo-Eco-Trop, no. 41, t. 3, 2017, pp. 503-518.

[10] Tahiri M., Tabyaoui H., El Hammichi F., Achab M., Tahiri A., El Hadi H.: Quantification of water erosion and sedimentation using empirical models in the Tahaddart watershed (Northwestern Rif, Morocco). Bulletin de l'Institut Scientifique, Section Sciences de la Terre, no. 39, 2017, pp. 87-101.

[11] Khali A., Ben Hamman Lech-Hab K., Raissouni A., El Arrim A.: Quantitative Mapping of Soil Erosion Risk Using GIS/USLE Approach at the Kalaya Watershed (North Western Morocco). Journal of Materials and Environmental Science, vol. 7, no. 8, 2016, pp. 2778-2795.

[12] Meliho M., Khattabi A., Mhammdi N., Zhang H.: Mapping of the water erosion risks of by the revised universal equation of soil losses, Remote sensing and GIS in the Ourika watershed (High Atlas, Morocco). European Scientific Journal, vol. 12, no. 32, 2016, pp. 277-297. https://doi.org/10.19044/esj.2016.v12n32p277. 
[13] Toumi S., Maddi M., Mahé G., Télesphore Brou Y.: Cartographie de l'érosion dans le bassin versant de l'Oued Mina en Algérie par télédétection et SIG. Hydrological Sciences Journal, vol. 58, no. 7, 2013, pp. 1542-1558. https://doi.org/ 10.1080/02626667.2013.824088.

[14] Lu D., Li G., Valladares G.S., Batistella M.: Mapping soil erosion risk in Rondonia, brazilian Amazonia: Using RUSLE, Remote Sensing and GIS. Land Degradation \& Development, vol. 15, no. 5, 2004, pp. 499-512. https://doi.org/10.1002/ ldr.634.

[15] Tesfamichael S.G.: Mapping potential soil erosion using RUSLE, Remote Sensing, and GIS: The case study of Weenen Game Reserve, KwaZulu-Natal. University of KwaZulu-Natal, Pietermaritzburg 2004 [M.Sc. thesis].

[16] Zhang H., Wei J., Yang Q., Baartman J.E.M., Gai L., Yang X., Li S., Yu J., Ritsema C.J., Geissen V.: An improved method for calculating slope length $(\lambda)$ and the LS parameters. The Global Journal of Soil Science - Geoderma, vol. 308, 2017, pp. 36-45. https://doi.org/10.1016/j.geoderma.2017.08.006.

[17] Talbi O., Mendas A., Bensaid A., Trache M.A.: Mise en place d'un système pour le suivi de l'érosion hydrique et la détection des zones prioritaire d'intervention contre l'envasement des retenues - Application au bassin versant de l'Isser (Tlemcen). Secheresse, vol. 13, no. 3, 2002, pp. 175-179.

[18] Chebbani R.: Etude à différentes échelles des risques d'érosion dans le bassin versant de l'Isser (Tlemcen). École nationale supérieure d'agronomie d'Alger, Algérie, 1996 [M.Sc. thesis].

[19] Benchettouh A.: L'érosion hydrique dans les régions marneuses du Tell oranais cas des bassins versants de la Mina (Relizane) et Kramis (Mostaganem). Université Abdelhamid Ibn Badis, Mostaganem, Algérie, 2019 [Ph.D. thesis]. http://e-biblio. univ-mosta.dz/handle/123456789/11692.

[20] van der Knijff J.M., Jones R.J.A., Montanarella L.: Soil Erosion Risk Assessment in Europe. Scientific and Technical Reports, EUR 19044 EN, Space Application Institute, Ispra, Italy, 2000. 